\title{
Delayed postoperative radiation therapy in local control of squamous cell carcinoma of the tongue and floor of the mouth
}

\author{
Retardo da radioterapia pós-operatória no controle local do carcinoma epidermoide \\ de língua e soalho de boca
}

\author{
Ali Amar ${ }^{1}$, Helma Maria Chedid ${ }^{1}$, Otávio Alberto Curionii ${ }^{1}$, Rogério Aparecido Dedivitis ${ }^{2}$, Abrão Rapoport ${ }^{1}$, \\ Claudio Roberto Cernea², Lenine Garcia Brandão ${ }^{2}$
}

\begin{abstract}
Objective: To evaluate the effect of time between surgery and postoperative radiation therapy on local recurrence of squamous cell carcinoma of the tongue and floor of the mouth. Methods: A total of 154 patients treated between 1996 and 2007 were selected considering local recurrence rate and time of the adjuvant radiotherapy. Results: Local recurrence was diagnosed in 54 (35\%) patients. Radiation therapy reduced the rate of local recurrences, although with no statistical significance. The time between surgery and initiation of postoperative radiotherapy did not significantly influence the risk of local recurrence in patients referred to adjuvant treatment $(p=0.49)$. Conclusion: In the presence of risk factors for local recurrence, a short delay in starting the adjuvant radiation therapy does not contraindicate its performance.
\end{abstract}

Keywords: Carcinoma, squamous cell/radiotherapy; Tongue neoplasms/ radiotherapy; Mouth neoplasms/radiotherapy; Time factors; Recurrence

\section{RESUMO}

Objetivo: Avaliar o efeito do tempo entre o tratamento cirúrgico e a radioterapia pós-operatória nas recidivas locais do carcinoma epidermoide de língua e soalho da boca. Métodos: Foram selecionados 154 pacientes tratados entre 1996 e 2007, considerando a frequência das recidivas locais e o tempo para início da radioterapia adjuvante. Resultados: As recidivas locais foram diagnosticadas em 54 (35\%) pacientes. A radioterapia reduziu a frequência de recidivas locais, embora sem significância estatística. 0 tempo entre a cirurgia e 0 início da radioterapia pós-operatória não influenciaram, de forma significante, no risco de recidivas locais entre 0 pacientes que tinham indicação de tratamento adjuvante $(p=0,49)$. Conclusão: $\mathrm{Na}$ presença de fatores de risco para recidiva local, um pequeno atraso no início da radioterapia adjuvante não contra-indica sua realização.

Descritores: Neoplasias de células escamosas/radioterapia; Neoplasias da língua/radioterapia; Neoplasias bucais/radioterapia; Fatores de tempo; Recidiva

\section{INTRODUCTION}

Usually, postoperative radiation therapy for patients with head and neck cancer is indicated when there is a high risk of recurrence. Ideally, radiation therapy should begin 6 weeks after surgical treatment. Delaying the start of adjuvant radiation therapy decreases its therapeutic effect due to hypoxia of the scarring tissue and repopulation with tumor cells. ${ }^{(1,2)}$ This is the reason why many studies tried to investigate the use of preoperative radiotherapy in 1960s and 1970s. In spite of the evidence provided by experimental studies, clinical trials have not shown that patients with malignant head and neck tumors stand to benefit from this therapeutical approach. ${ }^{(3)}$ Some authors believe that the total time, including waiting and treatment, is more important than the wait alone, and that a delay could be compensated by accelerated radiation therapy regimens. ${ }^{(4-6)}$ However, it still remains unclear if patients who are unable to start radiation therapy within the ideal timeframe can still benefit from late adjuvant treatment.

\footnotetext{
${ }^{1}$ Hospital Heliópolis, São Paulo, SP, Brazil.

2 Universidade de São Paulo, São Paulo, SP, Brazil.

Corresponding author: Abrão Rapoport - Rua Cônego Xavier, 276 - Heliópolis - Zip code: 04231-030 - São Paulo, SP, Brazil - Phone: (55 11) $3287-4347$ - E-mail: arapoport@uol.com.br

Received on: Oct 19,2013-Accepted on: July 28, 2014
}

Conflict of interest: none.

DOI: 10.1590/\$1679-45082014A03006 


\section{OBJECTIVE}

To assess the effect of delayed radiation therapy in the local control of squamous cell carcinoma of the tongue and floor of the mouth.

\section{METHODS}

The medical records of 184 patients with squamous cell carcinoma of the tongue and floor of the mouth (staging II to IV) we studied the patients underwent surgery between January 1996 and December 2007 and were treated at the Head and Neck and ENT Surgical Unit of the Hospital Heliópolis in the capital city of São Paulo. Thirty-one cases were excluded because the follow-up period was under 12 months; therefore, 153 patients met the inclusion criteria. As far as sex is concerned, 134 were male and the mean age was 52 years (range of 22 to 78 years). The local recurrence rate was investigated in relation to the time of postoperative radiation therapy, and the subjects were divided into three groups: less than 6 weeks after surgery, between 6 to 8 weeks after surgery and more than 8 weeks after surgery.

The criteria for indication of postoperative radiation therapy were heterogeneous, and certain patients failed to complete the treatment proposed. For analysis, only pT3 or pT4 staging and compromised or narrow surgical margins were considered as an indication for radiotherapy. When performed due to regional disease, radiation therapy was deemed as having no indication.

The statistical analysis used the $\chi^{2}$ test with the Yates correction, and only differences with $p<0.05$ were considered statistically significant.

The present study was approved by the IRB (Internal Research Board) of the Hospital Heliópolis under number 271/2004.

\section{RESULTS}

Fifty-four patients (35\%) presented local recurrence. While 74 patients received postoperative radiation therapy at the conventional fractioning and an average dose of 60Gy (41 to 72), 58 patients (78\%) received a dose $\geq 60 \mathrm{~Gy}$. Postoperative radiation therapy was initiated between 2 to 18 weeks after surgery.

Radiotherapy reduced the rate of local recurrence from $61 \%$ to $40 \%$ in those cases this modality had been indicated $(\mathrm{p}=0.07)$, and a trend towards statistical significance was observed. The rate of local recurrence in irradiated patients with a positive margin fell from $66 \%$ to $48 \%(p=0.47)$, and from $60 \%$ to $42 \%$ in patients who were pT3 or pT4 $(\mathrm{p}=0.19)$, although with not statistical significance.
Among the patients with an indication for adjuvant treatment, the time between surgery and postoperative radiotherapy did not affect local recurrence rate, and the result was not statistically significant $(p=0.49)$ as seen in table 1.

Table 1. Local recurrence according to indication and time of radiation therapy

\begin{tabular}{|c|c|c|c|c|}
\hline \multirow[b]{2}{*}{ Indication for RT } & \multirow[b]{2}{*}{$\begin{array}{c}\text { Time of RT } \\
\text { (weeks) }\end{array}$} & \multicolumn{2}{|c|}{ Local recurrence } & \multirow[b]{2}{*}{ Total } \\
\hline & & $\begin{array}{c}\text { Yes } \\
\text { n (\%) }\end{array}$ & $\begin{array}{c}\text { No } \\
\text { n (\%) }\end{array}$ & \\
\hline \multirow[t]{4}{*}{ Yes } & No & $21(61)$ & $13(39)$ & 34 \\
\hline & $<6$ & $11(44)$ & $14(56)$ & 25 \\
\hline & $6-8$ & $5(45)$ & $6(55)$ & 11 \\
\hline & $>8$ & $6(31)$ & $13(69)$ & 19 \\
\hline \multirow[t]{4}{*}{ No } & No & $9(18)$ & $39(82)$ & 48 \\
\hline & $<6$ & $1(11)$ & $8(89)$ & 9 \\
\hline & $6-8$ & 0 & $1(100)$ & 1 \\
\hline & $>8$ & $1(20)$ & $4(80)$ & 5 \\
\hline Total & & $54(35)$ & $99(65)$ & 153 \\
\hline
\end{tabular}

\section{DISCUSSION}

This study showed a lower local recurrence rate in patients who received postoperative radiation therapy, even after 6 weeks, albeit with no statistical significance. It may be the case that this delay did not significantly affect the outcome because regional recurrence was not an inclusion criterion. Another reason may be that, because cases with a poorer prognosis are required to delay starting adjuvant therapy due to postoperative complications, this was a rather homogeneous series in terms of primary site. Moreover, the higher doses that are currently used seem to compensate for this delay. In face of the existing literature, every possible effort should be made to start postoperative radiation therapy as early as possible. ${ }^{(2-8)}$ Although no time limit has been established, it is known that when facing recurrence, the exclusive use of radiation therapy can be disappointing. Therefore, there must be a moment in time as of which postoperative radiation therapy contributes very little to disease control. ${ }^{(9,10)}$ It has been suggested that 6 weeks be the time limit established to achieve local control, provided that the dose is lower than 60Gy. ${ }^{(1)}$ This is what we abide by at our practice; however, in 36 patients $(23.5 \%)$, this was not the case, either because of the patient's adverse conditions (dehiscences and fistulas) or because of certain practical limitations typical of a public hospital.

In the presence of several aggressiveness criteria or, more specifically, in cases which the diagnosis 
of recurrence is more difficult, such as in major reconstructions or when the resection borders make a second surgery unlikely, the use of radiation therapy is justified, even if later. However, it is precisely among patients with more risk factors that the delay in initiating radiation therapy seems to have the strongest impact in terms of locoregional recurrence. ${ }^{(8)}$ When treating mouth cancer, local recurrence remains an important reason for failure, but radiotherapy may also make it more difficult to diagnose recurrence, as well as to reduce the feasibility of performing a salvage surgery. ${ }^{(10)}$ Postoperative radiation therapy targets those fields that encompass the entire area under treatment, including both the bed of the primary site, as well as neck dissection areas, even when adjuvant treatment is indicated for one site only.

This study did not consider the indication of radiotherapy to treat neck metastases alone, since many of them were associated with recurrence at the primary site. Given the shortage of resources, the delay of adjuvant therapy has become a current issue and, unfortunately, in the case of squamous cell carcinoma of the upper air and digestive tracts, the efficacy of late radiation therapy has not been satisfactorily investigated.

\section{CONCLUSION}

In the presence of risk factors for local recurrence, a short delay in starting adjuvant radiotherapy does not represent a contraindication against this line of treatment. When postoperative radiotherapy was performed, a reduction in local recurrence, as well as in cases with positive margin and pT3 or pT4 was seen albeit with no statistical significance.

\section{REFERENCES}

1. Schiff PB, Harrison LB, Strong EW, Fass DE, Shah JP, Spiro R, et al. Impact of the time interval between surgery and postoperative radiation therapy on locoregional control in advanced head and neck cancer. J Surg Oncol. 1990;43(4):203-8.

2. Parsons JT, Mendenhall WM, Stringer SP, Cassisi NJ, Million RR. An analysis of factors influencing the outcome of postoperative irradiation for squamous cell carcinoma of the oral cavity. Int J Radiat Oncol Biol Phys. 1997;39(1):137-48.

3. Stein JJ. Preoperative radiation in the treatment of cancer. Calif Med. 1968; 109(3):185-90

4. Mendenhall WM, Hinerman RW, Amdur RJ, Malyapa RS, Lansford CD, Werning JW, et al. Postoperative radiotherapy for squamous cell carcinoma of the head and neck. Clin Med Res. 2006;4(3):200-8. Review.

5. Ang KK, Trotti A, Brown BW, Garden AS, Foote RL, Morrison WH, et al Randomized trial addressing risk features and time factors of surgery plus radiotherapy in advanced head-and-neck cancer. Int J Radiat Oncol Biol Phys. 2001;51(3):571-8.

6. Huang J, Barbera L, Brouwers M, Browman G, Mackillop WJ. Does delay in starting treatment affect the outcomes of radiotherapy? A systematic review. J Clin Oncol. 2003;21(3):555-63. Erratum in: J Clin Oncol. 2003;21(7):1424.

7. Langendijk JA, Ferlito A, Takes RP, Rodrigo JP, Suárez C, Strojan P, et al. Postoperative strategies after primary surgery for squamous cell carcinoma of the head and neck. Oral Oncol. 2010;46(8):577-85. Review.

8. Hinerman RW, Mendenhall WM, Morris CG, Amdur RJ, Werning JW, Villaret DB. Postoperative irradiation for squamous cell carcinoma of the oral cavity: 35-year experience. Head Neck. 2004;26(11):984-94.

9. Huang D, Johnson CR, Schmidt-Ullrich RK, Sismanis A, Neifeld JP, Weber J. Incompletely resected advanced squamous cell carcinoma of the head and neck: the effectiveness of adjuvant vs. salvage radiotherapy. Radiother Oncol. 1992;24(2):87-93.

10. Chedid HM, Franzi SA, Amar A, Lehn CN, Rapoport A, Dedivitis RA. 0 seguimento nas recidivas loco-regionais no câncer boca e orofaringe. Arq Int Otorrinolaringol. 2009;13(1):69-77. 